高齢者の運動頻度と実施時間の違いによる身体機能の差異

\title{
Difference in physical function due to differences in exercise frequency and duration of elderly people
}

\author{
白岩加代子, 村田 伸, 安彦 鉄平, 堀江 淳
}

Kayoko Shiraiwa, Shin Murata, Teppei Abiko, Jun Horie

要旨：本研究は，地域在住の女性高齢者を対象に運動頻度と実施時間について検証した。 日常生活における運動頻度と実施時間を基に，「運動なし」，「毎日30分未満」「ときどき 30分以上」，「毎日30分以上」の群に分け，身体機能と身体組成に差異がみられるか比較し た。その結果，身体機能に関しては，毎日30分以上の運動を行っている高齢者では，他の 群より，下肢筋力，バランス能力の評価が有意に良好な值を示した。また，毎日運動は実 施していても実施時間が30分未満の場合には, 日頃運動を行っていない高齢者と身体機能 に有意差は認められなかった。運動を行っていない高齢者では, 体脂肪率と Body Mass Index が運動を行っている高齢者よりも有意に高值を示した。これらのことから，高齢者の 身体機能の維持・向上のためには，毎日30分以上の運動を取り入れた生活を送ることが望 ましいと考える。

キーワード：女性高齢者, 運動頻度, 実施時間, 身体機能

\begin{abstract}
We investigated the frequency and duration of exercise for communitydwelling elderly women people. On the basis of the frequency of exercise and its duration in daily life, the subjects were divided into four groups: no exercise, $<30 \mathrm{~min} / \mathrm{day}, \geq 30 \mathrm{~min}$ sometimes, and $\geq 30$ min every day. Physical function and body composition were compared among these groups. As a result, regarding physical function, compared with other groups, elderly people performing exercise for $\geq 30$ min every day showed more favorable values for the lower extremity muscle strength and balance skills. In addition, no significant difference was noted in physical function between elderly people performing exercise for $<30 \mathrm{~min} /$ day and those not performing exercise on a daily basis. The latter group showed significantly higher values for the body mass index and body fat percentage than those performing exercise. The results of our study suggest that, in order for elderly people to maintain/improve their physical function, they should ideally perform exercise for $\geq 30$ min on a daily basis.
\end{abstract}

Key words: elderly women, frequency exercise, duration in daily life, physical function

受付日：2017年 6 月22日，採択日：2017年 8 月 1 日

京都橘大学健康科学部理学療法学科：⿳607-8175 京都府京都市山科区大宅山田34 電話番号：075-571-1111

Department of Physical Therapy, Faculty of Health Science, Kyoto Tachibana University

E-mail : shiraiwa@tachibana-u. ac.jp 


\section{I 、はじめに}

高齢者は加齢とともに身体機能が低下し，日常生活 での身体活動量も減少していく傾向にある11。世界保 健機構（World Health Organization：WHO）は, 高 齢者のための身体活動に関して，健康のためには30分 以上の身体活動を日常的に行うことや，筋力トレーニ ングは週 2 回以上行うことを推奨し，できる限り活発 に身体を動かす習慣をもつことが大切であると提唱し ている2)。わが国では，30分以上の運動を週 2 回以上 行うことを運動習慣の基準（健康日本21）とし ${ }^{3)}$, 文 部科学省のスポーツ振興基本計画では週 1 回以上の久 ポーツ実践を目標としている 効果について, Skelton $ら^{5)}$ やWolfson $ら^{6}$ は, 地域在 住高齢者を対象に週 3 回 1 時間の筋力強化を 12 週間行 い，筋力増強の効果があったことを報告している。ま た，角田ら ${ }^{7}$ は，体力水準が低い高齢者では，週に 1 回の運動介入でも身体機能は向上するが，体力水準が 中〜高水準の高齢者では, 週 1 回では効果が認められ なかったと報告している。

一方，アメリカスポーツ医学会 (The American College of Sports Medicine：ACSM）をはじめ, 高齢者 の健康維持のためには，身体活動を中等度の強度で30 分間，ほぼ毎日行うことを推奨し ${ }^{8.9}$ ，「健康日本21」 における65歳以上高齢者の健康づくりのための指針で は，運動も含めた身体活動を毎日40分行うことを掲げ ている3 。ただし, 毎日 1 回20分程度の集団リズム運 動を行っても，高齢者の精神面や身体機能に改善がみ

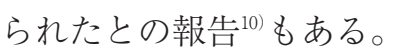

これまでの先行研究では，ある一定期間に運動や体 操などのトレーニングを実施し，運動の介入効果につ いて述べられた報告が多いが，対象者や介入方法など の違いによりその効果については必ずしも一定してお らず，高齢者の身体機能の維持・向上に効果的な運動 頻度と実施時間について十分に検討されているとは言 い難い。そこで本研究では, 地域在住の女性高齢者を 対象に運動頻度と実施時間について聞き取り調査を行 い，運動頻度と実施時間の違いにより，身体機能に差 異がみられるのか検討した。

\section{II. 対象と方法}

\section{1. 対 象}

本研究では，Y市の「生きがいづくりの会」に登録 している高齢者を対象とし, 体力測定会の開催を告知 し参加の意思を示した者を対象とした。測定は，2014
年 9 月 1 日〜 9 月19日に実施し，身体機能および身体 組成の評価を行った。除外対象は，介護認定を受けて いる者，脳血管疾患や関節リウマチ等の神経学的，整 形外科的既往による明らかな身体障害がある者，Mini -mental State Examination（MMSE）が23点以下の者 とした。また，事前に測定内容や測定結果の取り扱い について十分に説明し，書面にて同意を得られた者を 対象とした。体力測定会はY市の保健師の立会いのも とで行った。本研究は所属機関の研究倫理委員会の承 認を得て実施した（承認番号14- 5 ）。

\section{2. 方 法}

参加者には, 日常生活における義務的活動（労働, 家事，通勤など）を含めない運動・スポーツの実施状 況と実施時間についての聞き取り調査を行った。文部 科学省の高齢者用新体力テス卜実施要項 ${ }^{11)}$ を参考に, 運動頻度は，「運動はしていない」，「ときたま（月 1 〜 2 回程度)」,「ときどき (週 $1 \sim 2$ 回程度)」,「ほぼ 毎日」の 4 項目から 1 つ選択してもらった。また 1 日 の実施時間については，「30分未満」「「30分以上」の 2 項目の中から 1 つ選択してもらった。それらの結果 を基に，運動を行っていない群（「運動なし」群）, 毎 日運動は行っているが実施時間が30分未満の群（高頻 度短時間：「毎日30分未満」群), 週に $1 \sim 2$ 回程度, 30分以上の運動を行っている群（低頻度長時間：「と きどき30分以上」群), 毎日30分以上の運動を行って いる群（高頻度長時間：「毎日30分以上」群）に分類 した。群分けについては（表1）に示す。

測定は，身体機能の評価項目として，握力，長座体 前屈距離，上体起こし，開眼片脚立位時間，30秒間椅 子立ち上がりテスト（30-second chair-stand test：CS -30), $5 \mathrm{~m}$ 最速歩行時間, Timed Up \& Go test(TUG), 大腿四頭筋筋力, 足指把持力の測定を行った。身体組 成の評価として，骨格筋量，体脂肪率の測定を行った。

握力, 長座体前屈距離, 上体起こし, 開眼片脚立位 時間の測定は，文部科学省高齢者用新体力テストの実 施要項 ${ }^{15)}$ に従って実施した。握力の測定は左右 2 回ず

表 1 群分けの基準

\begin{tabular}{|c|c|}
\hline 群 & 運動頻度と実施時間 \\
\hline 運動なし & $\begin{array}{l}\text { 「運動はしていない」,「ときたま（月 } 1 〜 2 \\
\text { 回程度)」 }\end{array}$ \\
\hline 毎日30分未満 & 「ほぼ毎日」かつ「30分未満」 \\
\hline $\begin{array}{l}\text { ときどき30分以上 } \\
\text { 毎日30分以上 }\end{array}$ & 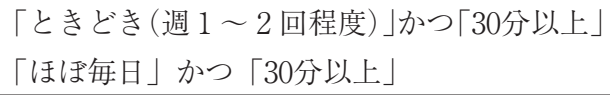 \\
\hline
\end{tabular}


つ行い，最大值（kg）を測定值とした。長座体前屈 距離の測定は 2 回行い, 最長距離 $(\mathrm{cm})$ を測定值と した。上体起こしの測定は，30秒間に繰り返し実施で きた回数を測定值とした。開眼片脚立位時間の測定は 左右 2 回ずつ行い, 最長時間（sec）を測定值とした。

CS-30の測定は，中谷ら ${ }^{12)} の$ 方法に従って実施した。 高さ $40 \mathrm{~cm}$ の椅子を使用し, 両腕を胸の前で組み, 両 脚を肩幅程度に広げた状態で腰掛けた姿勢を測定開始 肢位とした。この姿勢から立ち上がり再び着座する動 作をできるだけ多く繰り返すように指示し，30秒間に 立ち上がることができた回数を測定值とした。

$5 \mathrm{~m}$ 最速歩行時間の測定は, $5 \mathrm{~m}$ の歩行路（測定 区間）と両端に $3 \mathrm{~m}$ の助走路を設定して行い, 所要 時間はデジタルストップウォッチで測定した。歩行は できるだけ速く，最大努力にて歩くように指示した。 測定は 2 回行い, 最速值（sec）を測定值とした。

TUGの測定は, 島田ら ${ }^{13}$ の方法に従って実施した。 背もたれ付の椅子を使用し，背もたれによりかかった 姿勢で, 手は膝の上に置いた姿勢を測定開始肢位とし た。検者の合図で立ち上がり，できるだけ速く最大努 力にて前進し， $3 \mathrm{~m}$ 前方に配置してある目印を折り 返して再び椅子に腰掛けるまでの所要時間をデジタル ストップウォッチで測定した。測定は，2回行い，最 短時間（sec）を測定值とした。

大腿四頭筋筋力の測定は, 加藤ら ${ }^{14)}$ の方法に従って 実施した。椅子座位にて椅子の支柱にベルトを連結し， 下腿下垂位での等尺性筋力をハンドヘルドダイナモ メーター（アニマ社製， $\mu$-Tas F-1）を使用した。 測定の際は両上肢を胸の前で組み, 体幹垂直位, 膝関 節は $90^{\circ}$ 屈曲位とし, センサーパッドは下腿遠位部に 接触させた。測定中はセンサーパッドのずれを防止す るために検者が前方で固定して行った。測定は左右 2 回ずつ行い, 最大值 $(\mathrm{kg})$ を測定值とした。

足指把持力の測定は, 相馬ら ${ }^{15}$ の方法に従って足指 筋力測定器 (竹井機器工業製, 足指筋力測定器 II) を 使用した。端坐位にて両上肢を胸の前で組み, 体幹垂
直位, 膝関節は $90^{\circ}$ 屈曲位で, 把持バーを足指で把持 しやすい位置に調整し, 最大努力にて握るように指示 した。測定は左右 2 回ずつ行い, 最大值（kg）を測 定値とした。

身体組成は, 生体インピーダンス計測機器（Bio Space 社製，In Body430）を使用した。測定は裸足に て行い, 上肢は体幹からやや離した伸展位とし, 両下 肢は大腿部が接触しないようにやや外転位とした。ま た測定中は動かないことや会話はしないように指示し た。

各測定項目における測定值は, 平均值土標準偏差で 表し, 群間における各測定項目の比較には, 一元配置 分散分析を行った後，主効果を認めた項目については Tukeyの多重比較検定を用いて分析した。統計学的 解析にはSPSS Ver. 19を使用して行い, 統計学的有意 水準は 5 \%とした。

\section{III. 結 果}

群の内訳は,「運動なし」群45名,「毎日30分未満」 群23名,「ときどき30分以上」群199名,「毎日30分以 上」群49名であった。対象者の年齢, 身長, 体重, MMSE については，群間に有意差は認められなかった(表 2)。

測定值の結果は表 3 に示す。身体機能については, 上体起こしの回数は,「運動なし」群よりも「ときど き30分以上」と「毎日30分以上」群の方が有意に高值 を示した $(\mathrm{p}<0.05)$ 。CS-30は, 「運動なし」群より 「毎日30分以上」群の方が有意に高值を示した $(\mathrm{p}<$ 0.05)。大腿四頭筋筋力は, 「運動なし」と「毎日30分 未満」群より「毎日30分以上」群の方が有意に高值を 示した $(\mathrm{p}<0.05)$ 。開眼片脚立位時間, TUG, $5 \mathrm{~m}$ 最速歩行時間, 足指把持力では, 「毎日30分以上」群 が，他のすべての群より有意に良好な值を示した（p $<0.05)$ 。

身体組成については，体脂肪率と Body Mass Index （BMI）では「運動なし」群は他のすべて群よりも有 意に高值を示した $(\mathrm{p}<0.05)$ 。

表 2 対象者の内訳

\begin{tabular}{|c|c|c|c|c|c|c|}
\hline & 運動なし & 毎日30分未満 & $\begin{array}{l}\text { ときどき } \\
\text { 30分以上 }\end{array}$ & 毎日30分以上 & $\mathrm{F}$ 值 & $\mathrm{p}$ 值 \\
\hline 人数 (名) & 45 & 23 & 119 & 49 & & \\
\hline 年齢（歳） & $72.7 \pm 6.2$ & $74.9 \pm 7.3$ & $73.1 \pm 6.2$ & $71.3 \pm 5.3$ & 1.91 & 0.13 \\
\hline 身長（cm） & $149.9 \pm 5.2$ & $150.7 \pm 5.4$ & $150.2 \pm 5.0$ & $152.2 \pm 6.0$ & 2. 09 & 0.10 \\
\hline 体重（kg） & $53.4 \pm 8.5$ & $49.8 \pm 7.2$ & $50.3 \pm 8.3$ & $51.6 \pm 9.0$ & 1.71 & 0.17 \\
\hline MMSE（点） & $27.6 \pm 1.9$ & $27.4 \pm 2.2$ & $27.8 \pm 1.9$ & $28.0 \pm 1.9$ & 0.71 & 0.55 \\
\hline
\end{tabular}


表 3 群間における身体機能・身体組成の比較

\begin{tabular}{|c|c|c|c|c|c|c|}
\hline & $\begin{array}{c}\text { 運動なし } \\
(\mathrm{n}=45)\end{array}$ & $\begin{array}{c}\text { 毎日30分 } \\
\text { 未満(n=23) }\end{array}$ & $\begin{array}{l}\text { ときどき } \\
\text { 30分以上 } \\
(n=119)\end{array}$ & $\begin{array}{c}\text { 毎日30分 } \\
\text { 以上 }(n=49)\end{array}$ & $\begin{array}{c}\text { ANOVA } \\
\text { (F值) }\end{array}$ & post hoc \\
\hline 握力 $(\mathrm{kg})$ & $22.9 \pm 4.2$ & $23.9 \pm 3.7$ & $23.6 \pm 4.0$ & $23.7 \pm 4.3$ & 0.51 & \\
\hline 上体起こし（回） & $3.4 \pm 3.9$ & $5.1 \pm 4.2$ & $5.8 \pm 5.4$ & $6.9 \pm 5.8$ & $3.71^{*}$ & 「運動なし」く「ときどき」·毎日30分以上」 \\
\hline 長座体前屈距離 $(\mathrm{cm})$ & $34.1 \pm 9.1$ & $35.7 \pm 8.6$ & $36.1 \pm 7.8$ & $37.4 \pm 9.3$ & 1. 10 & \\
\hline 開眼片脚立位時間（sec） & $41.2 \pm 38.9$ & $48.2 \pm 44.4$ & $49.4 \pm 42.2$ & $71.4 \pm 40.7$ & $4.77^{*}$ & 「運動なし」·「30分未満」·ととどき」く「毎日30分以上」 \\
\hline TUG $(\mathrm{sec})$ & $6.2 \pm 1.6$ & $6.5 \pm 1.6$ & $6.2 \pm 1.5$ & $5.5 \pm 0.9$ & $3.56^{*}$ & 「運動なし」·「30分未満」·「ときどき」>「毎日30分以上」 \\
\hline CS-30 (sec) & $16.7 \pm 4.5$ & $17.3 \pm 4.3$ & $18.6 \pm 6.1$ & $20.2 \pm 5.6$ & 3. $49^{*}$ & 「運動なし」<「毎日30分以上」 \\
\hline $5 \mathrm{~m}$ 最速歩行時間（sec） & $2.8 \pm 0.5$ & $2.8 \pm 0.6$ & $2.8 \pm 0.9$ & $2.5 \pm 0.3$ & 2. $41^{*}$ & 「運動なし」·「30分未満」·「ときどき」>「毎日30分以上」 \\
\hline 大腿四頭筋筋力 $(\mathrm{kg})$ & $16.5 \pm 5.4$ & $15.0 \pm 4.3$ & $17.9 \pm 4.9$ & $19.7 \pm 5.4$ & $5.38^{*}$ & 「運動なし」·「30分未満」く「毎日30分以上」 \\
\hline 足指杷持力 $(\mathrm{kg})$ & $9.1 \pm 3.1$ & $8.4 \pm 4.3$ & $9.4 \pm 4.2$ & $12.5 \pm 10.3$ & 4. $12^{*}$ & 「運動なし」·「30分未満」·「ときどき」く「毎日30分以上」 \\
\hline 骨格筋量 $(k g)$ & $18.6 \pm 2.3$ & $18.2 \pm 2.0$ & $18.4 \pm 2.1$ & $19.0 \pm 2.7$ & 1.09 & \\
\hline 体脂肪率 $(\%)$ & $33.2 \pm 6.5$ & $29.7 \pm 6.5$ & $29.6 \pm 7.5$ & $29.4 \pm 7.7$ & 3. $12^{*}$ & $\lceil$ 運動なし」>「30分未満」·「ときどき」·「毎日30分以上」 \\
\hline BMI & $23.9 \pm 3.2$ & $22.0 \pm 2.6$ & $22.4 \pm 3.5$ & $22.2 \pm 3.6$ & $2.70^{*}$ & 「運動なし」>「30分未満」·「ときどき」·「毎日30分以上」 \\
\hline
\end{tabular}

握力, 長座体前屈距離, 骨格筋量については, 群間 に有意差は認められなかった。

\section{IV. 考 察}

地域在住の女性高齢者を対象とし, 運動頻度と実施 時間の違いにより，身体機能に差異がみられるのか検 討した。結果, 毎日30分以上の運動を行っている高齢 者は, 他の群に属する高齢者よりも筋力, 歩行能力, 立位バランスなどの身体機能が有意に優れていた。ま た体脂肪率や BMI については，運動を行っていない 高齢者が, 運動を行っている高齢者より有意に高值を 示した。

「毎日30分以上」群は，上体起こし，開眼片脚立位 時間, TUG, CS-30, $5 \mathrm{~m}$ 最速歩行時間, 大腿四頭 筋筋力, 足指把持力が他の群より有意に良好な值を示 した。高齢者の下肢筋力とバランス能力, 歩行能力の 間には密接な関係があることが指摘されている ${ }^{16-19)}$ 。 また山内ら ${ }^{20)} や D$ DeMichele $ら^{21)}$ は, 運動頻度や活動量 に依存して運動効果が得られることを報告している。 Braith ら ${ }^{22)}$ は, 運動頻度を週 2 回群, 週 3 回群, 何も 行わない群の 3 群に分け, 筋力増強に対する効果を検 討した結果, 週 2 回の頻度でも筋力増強の効果は認め られたが, その効果は週 3 回の効果の $80 \%$ 程度であっ たことを報告している。これらのことから, 運動頻度 やそれに伴う活動量が最も多いと思われる「毎日30分 以上」群が，他の群よりも身体機能が向上しており, 下肢筋力, バランス能力, 歩行能力に関する評価項目
が他の群より良好な結果を示したと推測した。

一方, 毎日運動は行っているが, 実施時間が30分未 満の高齢者は, 日頃運動を行っていない高齢者と比べ, すべての身体機能に有意差を認めなかった。平成25年 度体力・運動能力調査結果によると, 運動・スポーツ 実施時間が30分未満の群は，30分以上行う群より新体 力測定の合計点が低い值を示した ${ }^{23)}$ と報告されている。 また高齢者に対し, 週 3 日, 1 回30分のウォーキング では, 介入前の身体機能と有意差は認められなかっ た24)ことや，ラットを用いた研究では，1日10分およ び30分の運動を週 5 日実施した場合と運動を実施せず 通常飼育した群では，ヒラメ筋の重量比に差は生じず， 運動効果を認めなかった のことから，たとえ毎日運動を実施していたとしても， 実施時間が30分未満では，身体機能の維持・向上につ ながる運動量としては十分とはいえないと考えられた。 しかし，体脂肪率と BMI に関しては，「運動なし」群 の方が「毎日30分未満」群より有意に高值を示した。 体脂肪率の増加は生活習慣病との関連が強く, 特に女 性では体脂肪率と BMI は年齢と正の相関を示すこと が報告され ${ }^{26,27)}$ ，WHO は BMIの上昇に伴い健康障害 のリスクも上昇すると示している ${ }^{28)}$ 。本研究結果にお いて, 身体機能の評価では, 「運動なし」群と「毎日 30分未満」群では有意な差は認められなかった。しか し，身体組成の評価では，たとえ30分未満であっても 毎日あるいは時々でも運動を行った方が, 体脂肪率や BMI に差が生じることが明らかとなり，生活習慣病 
のリスク軽減に対しては，30分未満の運動であっても 効果が期待できると考える。また先行研究より, 日常 生活での身体活動量を増加するだけでは体力を向上さ

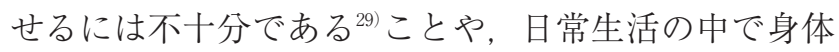
活動量を増やすことは何もしないよりは体力低下を招 きにくいが，定期的な運動を実施する方が効果をもた らす30ことが報告されている。さらに運動を長期間継 続している高齢者の生活自立度は高い ${ }^{311}$ ことが報告さ れており,これらのことから日常的に運動を取り入れ た生活を送ることが望ましいと考える。

本研究は，Y市の「生きがいづくりの会」に登録し ている高齢者を対象として募ったため, 対象者は運動 や健康への興味が高い集団であったと思われる。また 運動頻度と実施時間についての聞き取りから群分けを おこなったが，運動の継続期間や運動強度に関する調 查が不十分であった。今後は対象者の範囲を拡大する とともに男性高齢者についても検討し，運動頻度や実 施時間の違いが身体機能へ及ぼす影響について明確に していきたいと考えている。

\section{引用文献}

1）沢井史穂：加齢に伴う筋機能の低下とその予防のための運 動. 体育の科学, 1996, 46:112-122.

2) World Health Organization. Global recommendations on Physical Activity for Health. 2010, 30-31.

3）厚生労働省：健康づくりのための身体活動基準 2013. http://www.mhlw.go.jp/stf/houdou/2r9852000002xple-att /2r9852000002xpqt.pdf（2015年11月26日参照）

4）文部科学省 スポーツ基本計画 2012 http://www.mext.go.jp/component/a_menu/sports/detail /_icsFiles/afieldfile/2012/04/02/1319359_3_1.pdf （2015 年11月26日参照)

5) Skelton DA, Young A, Greig CA, et al.: Effects of resistance training on strength, power, and functional abilities of women aged 75 and older. J Am Geriatr Soc, 1995, 43(10): 1081-1087.

6) Wolfson L, Whipple R, Derby C, et al.: Balance and strenbth training in older adults: intervention gains and Tai Chi maintenance. J Am Geriatr Soc, 1996, 44(5): 498-506.

7）角田憲治, 尹 智暎, 辻 大士・他：体力水準の異なる高 齢者に対する, 短期間, 低頻度の運動介入の効果 Square -Stepping Exercise を中心とした運動介入. 厚生の指標, 2011, 58(2): $6-13$.

8) Pate RR, Pratt M, Blair SN, et al.: Physical activity and public health. A recommendation from the centers for disease control and prevention and the american college of sports medicine. JAMA, 1995, 273(5): 402-407.

9）加藤雄一郎, 川上 治, 太田壽城 : 高齢期における身体活 動と健康長寿. 体力科学, 2006, 55(2) : 191-206.
10）杉浦令人, 櫻井宏明, 和田 弘・他：要支援 - 軽度要介護 高齢者に対する集団リズム運動が心身機能にもたらす効果. 理学療法科学, 2010, 25(2) : 257-264.

11）文部科学省ホームページ新体力テスト実施要項（65～79歳 対象) http://www.mext.go.jp/component/a_menu/sports /detail/__icsFiles/afieldfile/2010/07/30/1295079_04.pdf (2014年 8 月25日参照)

12）中谷敏昭, 灘本雅一, 三村寛一・他：日本人高齢者の下肢 筋力を簡便に評価する30秒椅子立ち上がりテストの妥当性. 体育学研究, 2002, 47(5)：451-461.

13）島田裕之, 古名丈人, 大㴊修一・他：高齢者を対象とした 地域保健活動における Timed Up \& Go Testの有用性. 理 学療法学, 2006, 33(3) : 105-111.

14）加藤宗規, 山崎裕司, 柊 幸伸・他：ハンドヘルドダイナ モメーターによる等尺性膝伸展筋力の測定 - 固定ベルトの 使用が検者間再現性に与える影響 - 。総合リハ, 2001, 29 (11) : 1047-1050.

15）相馬正之，村田 伸，甲斐義浩 - 他：足趾把持力発揮時に おける下腿筋の筋活動. 理学療法科学, 2013, 28(4)：491 -494 .

16）池田 望, 村田 伸, 大田尾浩 - 他：地域在住女性高齢者 の握力と身体機能との関係. 理学療法科学, 2011, 26(2): 255-258.

17）鈴木堅二, 今田 元, 竹内正人 ·他：地域で自立生活して いる高齢者の歩行速度と生活関連活動との関連. 総合リ八, 2000, 28(10) : 955-959.

18）猪飼哲夫, 辰濃 尚, 宮野佐年 : 歩行能力とバランス機能 の関係.リハ医学, 2006, 43(12): 828-833.

19) Teresa M. Damush, Joseph G. Damush, Jr.: The effects of strength training on strength and Health-Reletes quality of life in older adult women. The Gerontologist, 1999, 39(6): 705-710.

20）山内秀樹, 米本恭三 : 老齢期の廃用性萎縮筋の機能回復に 及ぼす運動負荷の影響：ヒラメ筋の変化.リハ医学, 1997, 34(3) : 212-217.

21) DeMchele PL, Pollock ML, Graves JE, et al. : Isometric torso rotation strength : effect of traning frequency on its development. Arch Phys Med Rehabil, 1997, 78(1): 64-69.

22) Braith RW, Graves JE, Pollock ML, et al. : Comparison of 2 vs 3 days/week of variable resistance training during 10and 18-week programs. Int J Sports Med, 1989, 10(6): 450454.

23）文部科学省：平成25年度体力 - 運動能力調査報告書 - 運 動・スポーツの実施状況と体力 - . http://www.mext.go.jp /component/b_menu/other/_icsFiles/afieldfile/2014/10/ 14/1352495_07.pdf（2015年11月26日参照）

24）村田 伸, 大山美智江, 大田尾浩・他：在宅高齢者の運動 習慣と身体・認知 - 心理機能との関連. 行動医学研究, 2009, 15(1) : 1 - 9

25）山崎俊明, 立野勝彦, 灰原信英 - 他 : 運動負荷時間の違い がラット廃用性筋委縮の回復過程に及ぼす影響. 理学療法 学, 1998, 25(6) : 381-387.

26）金子美佐子, 宮村幸子, 神藤潤子：Body Mass Index ·体 脂肪率と生活習慣病との検討. 人間ドック, 2006, 21(1)： 
37-41.

27）山内知子, 小出あつみ, 武藤亜有：60歳以上の肥満群と非 肥満群の体重変化と生活習慣に関する比較. 日本食生活学 会誌, 2008, 18(4)：335-341.

28) World Health Organization : The world health report 2002, Chapter 4, Quantifying Selected Major Risks to Health. http://www.who.int/whr/2002/chapter4/en/ (2015年11 月26日参照)

29) Brach JS, Simonsick EM, Kritchevsky S, et al. : The association between physical function and lifestyle activity and exercise in the health, againg and body composition study. Journal of the American Geriatric Society, 2004, 52(4): 502509 .

30）重松良祐, 中垣内真樹, 岩井浩一・他：運動実践の頻度別 にみた高齢者の特徵と運動継続に向けた課題. 体育学研究, 2007, 52(2) : 173-186

31) Spirduso WW, Cronin DL : Exercise dose-response effects on quality of life and independent living in older adults. Med Sci Sports Exerc, 2001, 33(6): 598-608. 